\title{
СОДЕРЖАНИЕ
}

Л.А. Игошева, А.С. Гришина

Обзор основных методов укрепления грунтов основания

\section{Е.Н. Колесова}

Навесной вентилируемый фрасад: классификация элементов, входящих

в его состав, и проблемы, связанные с проектированием воздушного зазора

А.Н. Богомолов, В.В. Подтелков, Е.В. Цветкова, О.А. Богомолова

Взаимосвязь между прочностными характеристиками слагающего грунта и геометрией однородного ненагруженного откоса в предельном состоянии

В.В. Антипов, В.Г. Офррихтер

Современные неразрушающие методы изучения инженерно-геологического разреза 37

Ю.В. Бушмакова, М.Ю. Дьяконова, Е.П. Кузнецова

О развитии «зеленого каркаса» городской территории на примере г. Питтсбурга (США) ....50

С.П. Дорошенко, Ю.В. Саенко, А.Л. Невзоров

Определение коэффицциента Пуассона грунта на основе численного

моделирования лабораторных испытаний

А.С. Вшивков, Т.М. Бочкарева

Применение композитных материалов в технологии устройства буронабивных свай в обсадных трубах

М.В. Рубцова, А.М. Солдатенкова, О.В. Петренева

Риски инновационных проектов в строительстве

Б.Г. Ким, М.А. Степанов, Д.В. Волосюк

Способ устройства комбинированных фундаментов в зимний период

А.Н. Богомолов, О.А. Богомолова, Е.В. Цветкова, В.В. Подтелков

Особенности расчета устойчивости однородных и слоистых нагруженных

грунтовых откосов на основе анализа их напряженного состояния

Б.И. Кулачкин, А.А. Митькин

Инновации в геотехнике, связанные с новыми подходами к оценке качества буровых свай 106

А.И. Полищук, А.А. Филиппович, И.В. Семенов

Развитие метода оценки загружения отдельных фундаментов для их усиления в глинистых грунтах с использованием инъекционных свай

А.И. Полищук, А.С. Межаков

Оценка работы разделительных ограждений в слабых глинистых грунтах, устраиваемых

для защиты существующих зданий от влияния нового строительства

C. Швердm

Разработка метода расчета армирования оснований геосинтетическими материалами при провалах грунта и оседаниях земной поверхности (статья на нем. яз.) 